Поступна Олена Вікторівна кандидат наук 3 державного управління, доцент, доцент кафедри менеджменту навчально-науково-виробничого центру Національного університету цивільного захисту України, вул. Лермонтовська, 28, м. Харків, 61024, тел.: (057) 704-14-31, e-mail: posolv48@gmail.com, https://orcid.org/0000-0002-0622-0966

\title{
ЗМІСТ КОМПЛЕКСНОГО МЕХАНІЗМУ ПУБЛІЧНОГО УПРАВЛІННЯ РЕГІОНАЛЬНИМИ ОСВІТНІМИ СИСТЕМАМИ В УКРАЇНІ
}

Анотація. У статті здійснено аналіз наявних у наукових джерелах визначень ключових термінів обраної проблематики та запропоновано авторський підхід до визначення поняття «комплексний механізм публічного управління регіональними освітніми системами». На підставі результатів раніше проведених досліджень теоретичних і практичних аспектів публічного управління освітою, запропоновано комплексний механізм публічного управління регіональними освітніми системами та розкрити його зміст.

Доведено, що кожна складова комплексного механізму публічного управління регіональними освітніми системами має виконувати власну місію, що визначається змістовними і функціональними особливостями як на державному, так i на регіональному рівнях. Зокрема, правовий i організаційний механізми інтегрують і координують нормативно-правове та організаційно-адміністративне забезпечення (упорядковує відносини між державою і суспільством через нормативно-правові акти, визначення суб'єктів управління); економічний стратегічне і бюджетне забезпечення (регулює прогнозно-плановою фінансовою та інвестиційною діяльністю, бюджетуванням і фінансуванням розвитку освіти); соціальний - кадрове та мотиваційне забезпечення (створює умови для освітньопрофесійного та культурного розвитку людини); інформаційний - реалізує інформаційно-інноваційне забезпечення державного і регіонального розвитку системи освіти.

Запропонований комплексний механізм базується на теоретикометодологічних підходах комплексної взаємодії всіх суб'єктів управлінського процесу в освіті, владний вплив яких спрямовано на регіональні освітні системи як на об'єкти публічного управління. Об'єднує весь процес управління на рівні держави й регіону спільна стратегічна мета і завдання, при цьому в межах національної стратегії розвитку освіти розробляється регіональна стратегія, в якій 
враховуються специфічні особливості території, визначаються конкретні кількісні порогові індикатори, що забезпечують дієвий моніторинг сталого розвитку в цілому регіону.

Ключові слова: публічне управління освітою, комплексний механізм публічного управління регіональними освітніми системами, стратегія розвитку, цільові орієнтації, принципи, функції, форми, методи управління.

Postupna Olena Viktorivna $\mathrm{PhD}$ in Public Administration, Associate professor, Associate professor of the Department of Management at Training Research and Production Center at National University of Civil Defence of Ukraine, Lermontovska St., 28, Kharkiv, 61024, tel.: (057) 704-14-31, e-mail: posolv48@gmail.com, https://orcid.org/0000-0002-0622-0966

\title{
CONTENTS OF COMPLEX PUBLIC MANAGEMENT MECHANISM OF REGIONAL EDUCATIONAL SYSTEMS IN UKRAINE
}

\begin{abstract}
The article analyzes the definitions of key terms of the selected issues available in scientific sources and proposes the author's approach to the definition of "complex public management mechanism of regional educational systems". Based on the results of previous research on theoretical and practical aspects of public education management, a comprehensive mechanism for public management of regional education systems is proposed and its content is defined.

It is proved that each component of the complex public management mechanism of regional educational systems must fulfill its own mission, which is determined by the substantive and functional features at both the state and regional levels. In particular, legal and organizational mechanisms integrate and coordinate normative-legal and organizational-administrative support (regulating relations between the state and society through normative-legal acts, defining subjects of management); economic strategic and budgetary support (regulates forecast and planned financial and investment activities, budgeting and financing of education development); social staffing and motivational support (creating conditions for educational, professional and cultural development); information - implements information and innovation support of state and regional development of the education system.

The proposed complex mechanism is based on theoretical and methodological approaches to the complex interaction of all subjects of the management process in education, whose power is directed at regional educational systems as objects of public administration. The whole management process at the state and regional level is united by a common strategic goal and objectives; a regional strategy is developed within the national education development strategy, which takes into account specific features of
\end{abstract}


the territory, determines specific quantitative threshold indicators that provide effective monitoring of sustainable development of the whole region.

Keywords: public management of education, complex public management mechanism of regional educational systems, development strategy, target orientations, principles, functions, forms, management methods.

Постановка проблеми. В умовах проведення реформи децентралізації, сутність якої полягає в передачі значної частини повноважень, ресурсів та відповідальності від державної виконавчої влади до органів місцевого самоврядування, в країні змінюються акценти ролі і значення регіонального управління. Отримання і реалізація регіонами права вибору власної освітньої стратегії, тобто ¥ї регіоналізація, викликана ростом масштабів суспільного виробництва, ускладненням управління та зменшенням можливості враховувати на державному рівні специфіки розвитку кожного регіону.

Відмітимо, що в кожному регіоні України створена та функціонує власна регіональна освітня система (далі - РОС), яку ми визначаємо як підсистему національної освіти та соціально-економічного комплексу регіону, яка має власну історію, традиції, цінності, особливості, функціонування якої спрямовано на забезпечення розвитку людського капіталу в регіоні шляхом надання населенню необхідних освітніх послуг. РОС є самостійною складноорганізованою системою, яка в свою чергу складається з окремих взаємопов'язаних між собою підсистем: нормативно-правового забезпечення, закладів освіти та наукових установ, учасників освітнього процесу та їх організацій (об'єднань), освітніх програм і кваліфікацій, органів управління у сфері освіти та механізмів управління. Від ефективності діяльності всіх перелічених підсистем залежить результативність функціонування РОС як об'єкта управлінського процесу. Однак, практичний досвід свідчить про існування низки проблем у функціонуванні в управлінні РОС, a саме неефективність функціонування механізмів управління. На наше переконання, ефективність існуючих механізмів підвищується тоді, якщо вони діють як комплексний механізм. Це і визначило напрямок дослідження.

Аналіз останніх досліджень і публікацій. У науці державного управління українськими дослідниками напрацьовано достатньо наукових розробок щодо визначення структури, складових елементів, змісту, властивостей, специфіки та особливостей механізмів управління. Однак, і досі немає чітко визначеної їх класифікації. У науковому просторі йдуть жваві дискусії з приводу цього питання. Вчені виділяють цілі групи механізмів - державні та цільові державні механізми, механізми управління державою, механізми процесу та механізми системи управління, механізми взаємодії суб'єктів управління, недержавні механізми управління тощо. 
Останнім часом новим науковим напрямом стає дослідження теоретикометодологічних засад публічного управління як специфічного виду управлінської діяльності в умовах сучасних суспільних перетворень, формується відповідна термінологічна система та наукова методологія. 3’являються публікації, у яких досліджуються механізми публічного управління, порядок взаємодії публічних інституцій, що так чи інакше впливає на певну сферу життєдіяльності суспільства, та визначається місце органів державної влади в цьому процесі. Зокрема, механізми публічного управління $є$ предметом дослідження таких українських учених, як В. Абрамов, Я. Жовнірчик, О. Загороднюк, О. Коротич, Ю. Легеза, Л. Малюга, Б. Мельниченко, Г. Панченко, О. Рєзнік, О. Слюсарчук, О. Сукманова, Я. Чернятевич, Ю. Шаров та ін. Проблему визначення структури комплексного механізму державного управління порушують у своїх наукових працях Т. Гнацюк, Л. Грень, І. Мартинюк, В. Медвідь, М. Мельник, Б. Лемішко, О. Тимошенко, Ю. Ульянченко, О. Якименко, Н. Яркіна та ін. Однак, вчені розглядають цей механізм лише в рамках державного управління, не беручи до уваги, що сучасним трендом є максимальне залучення громадськості до управлінського процесу, співпраця держави з інституціями громадянського суспільства.

Отже, мета статті - здійснити аналіз наявних у наукових джерелах визначень ключових термінів обраної проблематики («механізми публічного управління», «комплексний механізм публічного управління», «регіональне управління») та запропонувати авторський підхід до визначення поняття «комплексний механізм публічного управління регіональними освітніми системами». Крім того, на підставі результатів раніше проведених досліджень теоретичних і практичних аспектів публічного управління освітою, запропонувати схематичне бачення комплексного механізму публічного управління РОС та розкрити його теоретичні сутність і зміст.

Виклад основного матеріалу. Перш ніж перейти до розгляду визначеної проблематики, хотілось би зазначити, що в нашому дослідженні ми віддаємо пріоритетність більш усталеним визначенням базової термінологічної конструкції - тим, що наведені у словниках з державного/публічного управління. Почнемо із визначення поняття «механізм публічного управління», яке трактується як «сукупність засобів, методів та важелів держави, спрямованих на формування, реалізацію та досягнення пріоритетних цілей у сфері публічного управління, що базуються на принципах наукового обгрунтування, об'єктивності, цілісності, узгодженості та чіткій скоординованості дій суб'єктів публічного управління, iз одного боку, та злагодженої, конструктивної взаємодії об'єктів публічного управління - 3 другого» [1]. Тож, механізм публічного управління є сукупністю інструментів, дій та суб’єктів, які задіяні в управлінському процесі. Ключова роль у механізмі публічного управління, згідно з визначенням, відводиться державі, 
діяльність якої спрямована на досягнення пріоритетних управлінських цілей. При цьому обов’язковими елементами механізмів державного управління є принципи, функції, методи, інформація, технологія та технічні засоби.

Видом державного управління, його важливою складовою, що здійснюється органами державної влади адміністративно-територіальних одиниць у межах їх компетенції, мета яких полягає в забезпеченні комплексного розвитку регіонів 3 метою підвищення ступеня соціально-економічних потреб населення [2], до яких належать i освітні послуги, $\epsilon$ регіональне управління, яке, як правило, здійснюється на основі державної регіональної політики як складової національної стратегії соціально-економічного розвитку країни. Оскільки РОС $є$ складовою соціально-економічного комплексу регіону, а отже i складовою соціально-економічного комплексу країни, то в такому випадку публічне управління РОС можна розглядати як публічне управління соціальним розвитком, в якому РОС виступають об’єктом управління. У такому разі механізми публічного управління РОС складають сукупність різноманітних принципів, функцій, форм, методів, інструментів, технологій, засобів, ресурсів та спрямовані на формування, реалізацію й досягнення пріоритетних цілей щодо розвитку освіти в певному регіоні, що з одного боку, потребує чіткої узгодженості дій суб'єктів управління, а 3 іншого - конструктивної та злагодженої взаємодії об'єктів управління. За характером впливу та залежно від засобів, які використовуються у конкретних механізмів управління, вони можуть бути політичними, правовими, організаційними, економічними, соціальними, та, в той же час відповідно до основних сфер суспільної діяльності можуть бути комплексними.

На жаль, у спеціальних словникових виданнях не надається визначення поняттю «комплексний механізм», тому звернемося до трактування цього поняття, яке надають у своїх працях учені, та згрупуємо їх дослідження за тотожністю у підходах. Зазначимо, що переважна більшість учених розглядають комплексний механізм як систему (сукупність) механізмів управління (О. Кучабський, О. Нєма, Н. Нижник, Л. Приходченко, Ю. Ульянченко, О. Федорчак, В. Шевченко). Інші визначають його як ряд засобів цілеспрямованого впливу органів державного управління (В. Бакуменко, Д. Безносенко, І. Варзар та ін.); як систему практичних заходів, засобів, важелів, стимулів (В. Медвідь, М. Мельник, О. Тимошенко, О. Якименко) і навіть як процес функціонування місцевих бюджетів (О. Голинська).

Систематизувавши різні погляди науковців щодо механізмів управління та самого процесу публічного управління, його особливостей на рівні регіону, пропонуємо трактувати комплексний механізм публічного управління регіональними освітніми системами як сукупність конкретних механізмів публічного управління, за допомогою яких реалізуються публічно-управлінські 
впливи на регіональні освітні системи, що базуються на основоположних принципах, цільовій орієнтації, функціональній діяльності кожного суб'єкта управління з використанням відповідних форм і методів управління. Схематично зміст комплексного механізму публічного управління РОС представлено на рис. 1. Зазначимо, що головною метою розробки комплексного механізму публічного управління РОС $є$ комплексний підхід досягнення поставленої стратегічної національна стратегічна мета розвитку освіти визначена на державному рівні у відповідному документі - у Національній стратегії розвитку освіти в Україні на період до 2021 року (далі - Національна стратегія) - та полягає у підвищення «доступності якісної, конкурентоспроможної освіти відповідно до вимог інноваційного сталого розвитку суспільства, економіки; забезпечення особистісного розвитку людини згідно 3 іï індивідуальними здібностями, потребами на основі навчання протягом життя» [3]. Варто звернути увагу, що розвиток освіти за визначеними у документі завданнями, напрямами та заходами обмежено конкретним роком - до 2021 року, тобто сьогодні (станом на лютий 2021 р.) вже можна підвести підсумки й проаналізувати, чи досягли тих результатів, що були намічені. Аналіз стану системи освіти та освітня практика свідчить, що очікувані результати виконані частково, а отже потребують подальшої реалізації Національної стратегії з корегуванням їі завдань.

Також звертаємо увагу, що Національна стратегія була розроблена з метою конкретизації основних шляхів реалізації концептуальних ідей і поглядів розвитку освіти, визначених у раніше затвердженому документі (у 2002 р.) - Національній доктрині розвитку освіти [4], який є чинним і досі. В документі визначаються основні напрями розвитку освіти у першій половині XXI ст., тобто можна стверджувати, що в цьому документі визначено стратегію розвитку освіти до 2025 року.

Документом вищого рівня в кожному регіоні є стратегія, в якій визначені пріоритетні цілі розвитку області у найближчій перспективі. Так, у 2020 р. кожний регіон України затвердив стратегію розвитку області на 2021 - 2027 роки. 
Національна стратегічна мета розвитку освіти

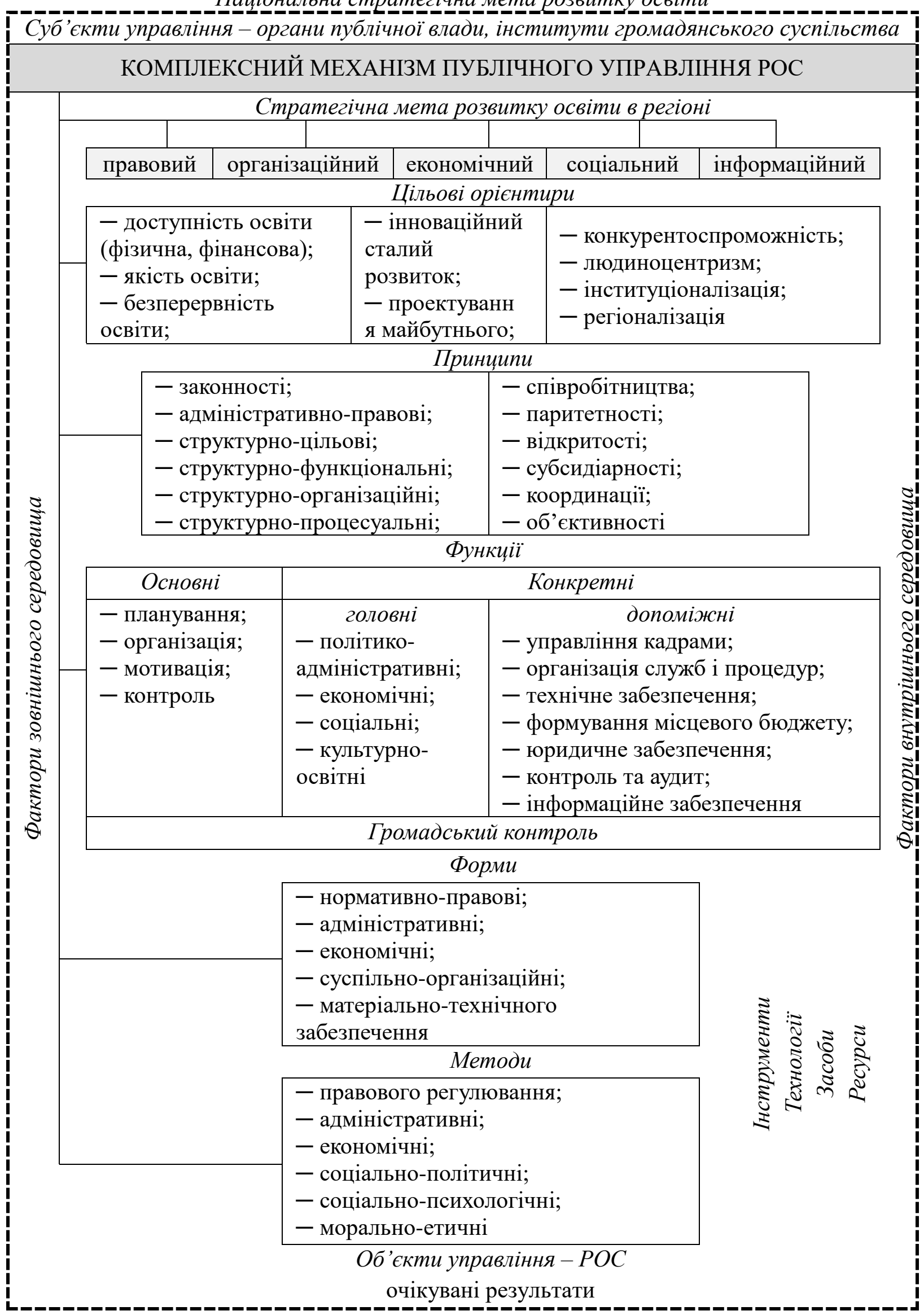

Рис. 1. Зміст комплексного механізму публічного управління регіональними освітніми системами

(авторська розробка) 
В основу визначення стратегічних цілей розвитку освіти на рівні регіону покладено цілі Національної стратегії та цілі регіонального розвитку соціальної інфраструктури, в тому числі й освіти. В регіональних стратегічних документах прописані вихідні положення сценаріїв розвитку регіонів (базові (інерційні), оптимістичні (інноваційні) та песимістичні), що сформовані на основі результатів SWOT-аналізів, дослідження соціально-економічного стану області, виявлених проблем, а також з урахуванням міжнародних, національних i регіональних прогнозних документів 3 розвитку соціальної сфери, в тому числі з розвитку освіти. Крім того, визначено стратегічні та оперативні цілі розвитку регіону, завдання щодо їх реалізації. Наприклад, у Стратегії розвитку Харківської області відповідно до оперативної цілі 1.3. Забезпечення доступної і якісної освіти на всіх рівнях, визначено низку завдань: задоволення потреби у здобутті дошкільної й позашкільної освіти та оптимізація ефективної мережі закладів повної загальної освіти 3 урахуванням результатів демографічного прогнозу та специфіки розташування населених пунктів; реорганізація малокомплектних сільських шкіл; забезпечення закладів освіти сучасною комп'ютерною технікою; забезпечення якісного надання послуг із перевезення дітей у сільській місцевості; модернізація професійної (професійно-технічної) освіти відповідно до потреб регіонального ринку праці; розвиток дуальної та інклюзивної освіти у закладах вищої освіти; розбудова системи освіти впродовж життя; створення технологічних платформ на базі наукових установ і закладів вищої освіти у смарт-спеціалізованих напрямках розвитку економіки та ін. [5].

Зауважимо, що для вирішення багатоцільових завдань з розвитку РОС на рівні регіонів побудовано систему публічного управління, що представлена сукупністю органів державного управління та місцевого самоврядування, що мають владно-організуючий та регулюючий вплив на сферу освіти 3 метою іï впорядкування, створення належних умов для ऑiі функціонування й розвитку 3 метою досягнення цілей освітньої політики, а також представників інститутів громадянського суспільства в сфері освіти. Результатом управлінського процесу мають бути прогнозовані результати.

Стратегічні цілі з розвитку освіти на рівні регіону реалізуються суб'єктами публічного управління за допомогою механізмів управління. Принципово важливими складовими комплексного механізму публічного управління РОС $є$ конкретні механізми управління - правовий, організаційний, економічний, соціальний, інформаційний. Кожен з цих механізмів пов'язаний між собою, тому часто можуть об'єднуватись між собою (наприклад, організаційно-правовий, соціально-економічний тощо), однак у межах комплексного механізму вони регулюються централізовано з метою забезпечення ефективного функціонування та розвитку РОС. 
Розглянемо більш детально кожен 3 механізмів та визначимо їх зміст. Почнемо 3 правового механізму, який закладає правові основи для функціонування інших механізмів, всієї системи РОС та представлений комплексом взаємопов'язаних юридичних засобів (міжнародно-правові акти в сфері освіти, міжнародні стандарти, законодавче та нормативно-правове забезпечення розвитку освіти, національні стандарти якості освіти), які необхідні для досягнення мети. Нами раніше вже було розглянуто механізм правового регулювання процесу публічного управління освітою, проаналізовано стан національного освітнього законодавства, визначено особливості його формування, здобутки й недоліки та окреслено можливі шляхи удосконалення цього механізму [6]. На рівні регіонів суть правового механізму полягає у забезпечення правових засобів і форм впливів шляхом прийняття нормативно-правових актів та вироблення засобів їх застосування 3 метою забезпечення функціонування й розвитку РОС, правового регулювання правовідносин між суб'єктами в освітній сфері. Актами також регулюються методологія, правові основи фінансовоекономічної, соціально-психологічної, науково-методичної, матеріальнотехнічної, педагогічної підтримки учасників освітнього процесу.

Організаційний механізм представлений системою суб'єктів публічного управління, відповідними регламентуючими документами (програмними i статутними документами, регламентами, положеннями, посадовими інструкціями), системою контролю, аудиту, моніторингу, а також ліцензійними та акредитаційними умовами та положеннями. Суть організаційного механізму управління щодо розвитку РОС полягає в організаційно-адміністративному забезпеченні управлінського процесу - визначенні організаційної структури управління РОС та форм відповідної управлінської діяльності.

Щодо економічного механізму, то потрібно чітко відрізняти його суть на рівні держави (стратегічне забезпечення - фінансові, цінові, інвестиційні, податкові документи; державні програми та стратегії розвитку; економічна політика) та на рівні регіону (бюджетне забезпечення - бюджетне фінансування; податки; кредити; гранти; кошти фізичних і юридичних осіб). В цілому можна стверджувати, що економічний механізм управління на рівні регіону в освітній сфері спрямований насамперед на підтримку РОС та створює умови для розвитку здорової конкуренції в сфері освіти - здатність закладів освіти та учасників освітнього процесу діяти в умовах ринкових відносин й отримувати при цьому прибуток, достатній для освітньо-науково-виробничого вдосконалення.

Соціальний механізм управління є багатогранним комплексом засобів, методів і технологій, спрямованих на регулювання відносин суб’єктів освітньої сфери (окреслює соціальні зв'язки), формування системи соціального захисту, створення морально-психологічного підгрунтя та мотиваційних умов професійної 
діяльності - вмотивування працівників і здобувачів освіти до науково-освітньої діяльності, забезпечення професійного розвитку колективів закладів освіти та інше. Тож соціальний механізм управління спрямований на кадрове (підготовку, перепідготовку, підвищення кваліфікації педагогічних, науково-педагогічних та керівних кадрів в освіті; визначення соціального статусу, умов атестації та самоосвіти персоналу) та мотиваційне (толерантне ставлення; виплати премій та пропозиція пільгових умов учасникам освітнього процесу; формування системи норм, цінностей та переконань) забезпечення РОС.

I останній конкретний механізм, що є складовою комплексного механізму публічного управління РОC, - інформаційний механізм спрямований на формування вертикальної і горизонтальної мережі прийняття та поширення інформації щодо розвитку РОС, на створення каналів постійного обміну інформацією 3 інститутами громадянського суспільства та 3 окремими громадянами регіону. Фактично інформаційний механізм вміщує в собі інформаційно-аналітичну (збір, аналіз та поширення інформації; моніторинг та оцінювання результатів діяльності), інформаційно-ресурсну (нормативно-правові, кадрові, матеріально-технічні, фінансові ресурси і компоненти), інформаційнокомунікаційну (інформаційні технології, канали передачі інформації) та інституційну (організації, заклади, установи, що збирають, обробляють та розповсюджують інформацію) складові.

Слід зазначити, що комплексний механізм публічного управління РОС базуються на основоположних принципах, цільовій орієнтації, управлінських функціях, а також формах, методах, інструментах, технологіях, засобах і ресурсах управління. Так, цільовими орієнтаціями цього механізму виступають: фізична та фінансова доступність освіти, ii якість, безперервність; інноваційний сталий розвиток; проектування майбутнього; конкурентоспроможність; людиноцентризм; інституціоналізація та регіоналізація. Принципами $є$ як найбільш відомі, наприклад, законності, об'єктивності, відкритості, координації, паритетності, субсидіарності, паритетності, співробітництва, так i структурні принципи адміністративно-правові, структурно-цільові (побудова «дерева цілей» управління), структурно-функціональні (взаємозв'язки побудови функціональної структури управління), структурно-організаційні (взаємозв'язки побудови організаційної структури управління) та структурно-процесуальні (взаємозв'язки раціонального і ефективного ведення управлінської діяльності).

Серед функцій управління можна відмітити основні (планування, організація, мотивація, контроль), конкретні, що в свою чергу складаються 3 конкретноголовних (політико-адміністративних, економічних. Соціальних, культурноосвітніх) i конкретно-допоміжних (управління кадрами, організація служб i процедур, технічне забезпечення, формування місцевого бюджету, юридичне 
забезпечення, контроль та аудит, інформаційне забезпечення), а також окремою новою функцією, що й визначає публічне управління, $є$ громадський контроль. Щодо форм управління, то їх можна класифікувати за уніфікованими і зовнішніми ознаками формалізованих видів конкретних результатів діяльності суб'єктів управління освітнього процесу, які створюють нормативно-правове, адміністративне, економічне, суспільно-організаційне, матеріально-технічного забезпечення досягнення поставленої мети управління.

Методи управління $є$ сукупністю універсальних i специфічних способів i прийомів, які застосовуються при прийняті й реалізації управлінських рішень (правового регулювання, адміністративні, економічні, соціально-політичні, соціально-психологічні, морально-етичні).

Висновки. Підсумовуючи можна зазначити, що кожна складова комплексного механізму публічного управління РОC має виконувати власну місію, що визначається змістовними і функціональними особливостями як на державному, так і на регіональному рівнях. Наприклад, правовий і організаційний механізми інтегрують і координують нормативно-правове та організаційно-адміністративне забезпечення (упорядковує відносини між державою i суспільством через нормативно-правові акти, визначення суб'єктів управління); економічний стратегічне і бюджетне забезпечення (регулює прогнозно-плановою фінансовою та інвестиційною діяльністю, бюджетуванням і фінансуванням розвитку освіти); соціальний - кадрове та мотиваційне забезпечення (створює умови для освітньопрофесійного та культурного розвитку людини); інформаційний - реалізує інформаційно-інноваційне забезпечення державного i регіонального розвитку системи освіти. Отже, державні механізми управління проектуються на регіональний рівень і складають систему конкретних механізмів регіонального управління освітою. Представлені в комплексному механізмі публічного управління РОС конкретні механізми не $\epsilon$ обов'язковими або достатніми, варіюватися може, як їх кількість, так і їх скомбінованість, тобто вони можуть об'єднуватись у два чи більше механізмів з метою досягнення визначеної мети.

Запропонований комплексний механізм базується на теоретикометодологічних підходах комплексної взаємодії всіх суб'єктів управлінського процесу в освіті, владний вплив яких спрямовано на РОС як на об'єкти публічного управління. Об’єднує весь процес управління на рівні держави й регіону спільна стратегічна мета і завдання, при цьому в межах національної стратегії розвитку освіти розробляється регіональна стратегія, в якій враховуються специфічні особливості території, визначаються конкретні кількісні порогові індикатори, що забезпечують дієвий моніторинг сталого розвитку в цілому регіону.

Подальші наукові дослідження доцільно спрямувати на розробку науково- 
практичних рекомендацій 3 удосконалення конкретних механізмів, що $\epsilon$ складовими компонентами комплексного механізму публічного управління РОС.

\section{Лimepamypa:}

1. Панченко Г. О. Механізми публічного управління / Г. О. Панченко // Публічне управління : термінол. слов. / уклад. : В. С. Куйбіда, М. М. Білинська, О. М. Петроє та ін. ; за заг. ред. В. С. Куйбіди, М. М. Білинської, О. М. Петроє. - К. : НАДУ, 2018. - С. 87.

2. Бакуменко В. Д., Штика Л. Г. Регіональне управління / В. Д. Бакуменко, Л. Г. Штика // Енциклопедичний словник з державного управління / уклад. : Ю. П. Сурмін, В. Д. Бакуменко, А. М. Михненко та ін. ; за ред. Ю. В. Ковбасюка, В. П. Трощинського, Ю. П. Сурміна. - К. : НАДУ, 2010. - С. 612-613.

3. Указ Президента України «Про Національну стратегію розвитку освіти в Україні на період до 2021 року» [Електронний ресурс]. - Режим доступу : https://zakon.rada.gov.ua/laws/show/ 344/2013\#Text.

4. Указ Президента України «Про Національну доктрину розвитку освіти» [Електронний ресурс]. - Режим доступу : https://zakon.rada.gov.ua/ laws/show/347/2002\#Text.

5. Стратегія розвитку Харківської області на 2021 - 2027 роки [Електронний ресурс]. - Режим доступу : https://kharkivoda.gov.ua/content/ documents/1026/102538/files/\%D0\%A1\%D1\% 82\%D1\%80\%D0\%B0\%D1\%82\%D0\%B5\%D0\%B3\%D1\%96\%D1\%8F.pdf.

6. Поступна О. В. Механізм правового регулювання процесу публічного управління освітою / О. В. Поступна // Наукові перспективи (Серія «Державне управління, Серія «Право», Серія «Економіка», Серія «Медицина»). - К., 2021. - Вип. № 1 (7). - С. 239 - 250.

\section{References:}

1. Panchenko, H.O. (2018). Mekhanizmy publichnoho upravlinnia [Mechanisms of public administration]. Publichne upravlinnia : terminol. slov. - Public administration: glossary. V.S. Kuibida (Ed.). Kyiev: NADU, (p. 87) [in Ukrainian].

2. Bakumenko, V.D., \& Shtyka, L.H. (2010). Rehionalne upravlinnia [Regional management]. Entsyklopedychnyi slovnyk z derzhavnoho upravlinnia - Encyclopedia of Public Administration. Yu.V. Kovbasiuk (Ed.). Kyiev: NADU, (pp. 612-613) [in Ukrainian].

3. Ukaz Prezydenta Ukrainy "Pro Natsionalnu stratehiiu rozvytku osvity v Ukraini na period do 2021 roku" [Decree of the President of Ukraine "On National Strategy of Education Development in Ukraine until 2021"]. (n.d.). zakon.rada.gov.ua. Retrieved from https://zakon.rada.gov.ua/laws/show/344/2013\# Text [in Ukrainian].

4. Ukaz Prezydenta Ukrainy "Pro Natsionalnu doktrynu rozvytku osvity" [Decree of the President of Ukraine "On National Doctrine of Education Development"]. (n.d.). zakon.rada.gov.ua. Retrieved from https://zakon.rada.gov. ua/laws/show/347/2002\#Text [in Ukrainian].

5. Stratehiia rozvytku Kharkivskoi oblasti na 2021 - 2027 roky [Kharkiv Region Development Strategy of for 2021 - 2027]. (n.d.). kharkivoda.rada.gov.ua. Retrieved from https://kharkivoda.gov.ua/content/documents/1026/102538/files/\% D0\%A1\%D1\%82\%D1\%80\%D0\% B0\%D1\%82\%D0\%B5\%D0\%B3\%D1\%96\%D1\%8F.pdf [in Ukrainian].

6. Postupna, O.V. (2021). Mekhanizm pravovoho rehuliuvannia protsesu publichnoho upravlinnia osvitoiu [Mechanism of legal regulation of the public management process in education]. Naukovi perspektyvy - Scientific Prospects (Seriia «Derzhavne upravlinnia, Seriia «Pravo», Seriia «Ekonomika», Seriia «Medytsyna»), 1 (7), 239-250 [in Ukrainian]. 